\title{
1 Chlorine in wadsleyite and ringwoodite: an experimental study
}

2 Mathilde Roberge ${ }^{1}$, Hélène Bureau ${ }^{1}$, Nathalie Bolfan-Casanova ${ }^{2}$, Caroline Raepsaet ${ }^{3}$,

3

21 Corresponding author : Hélène Bureau e-mail : helene.bureau@impmc.upmc.fr
Fiquet ${ }^{1}$.

\author{
${ }^{1}$ Institut de Minéralogie, de Physique des Matériaux et de Cosmochimie (IMPMC), Sorbonne \\ Universités - UPMC Univ. Paris 06, CNRS UMR 7590, Muséum National d'Histoire Naturelle, IRD \\ UR 206, 4 place Jussieu, 75252 Paris Cedex 05, France \\ ${ }^{2}$ Laboratoire Magmas et Volcans, Université Blaise Pascal, Clermont-Ferrand, France \\ ${ }^{3}$ LEEL, NIMBE, CEA, CNRS, Université Paris-Saclay, CEA Saclay, 91191 Gif-sur-Yvette Cedex, \\ France \\ ${ }^{4}$ Université Grenoble Alpes, ISTerre, UMR5275 F-38041 Grenoble cedex 9, France \\ ${ }^{5}$ UMET Lille
}

Keywords: Chlorine, transition zone, experimental study, volatiles

\section{For submission to Earth and Planetary Sciences Letters}




\begin{abstract}
We report concentrations of Chlorine $(\mathrm{Cl})$ in synthetic wadsleyite $(\mathrm{Wd})$ and ringwoodite (Rw) in the system $\mathrm{NaCl}-(\mathrm{Mg}, \mathrm{Fe}){ }_{2} \mathrm{SiO}_{4}$ under hydrous and anhydrous conditions. Multi-anvil press experiments were performed under pressures (14-22 GPa) and temperatures (1100$1400^{\circ} \mathrm{C}$ ) relevant to the transition zone (TZ: 410-670 km depth). $\mathrm{Cl}$ and $\mathrm{H}$ contents were measured using Particle Induced X-ray Emission (PIXE) and Elastic Recoil Detection Analysis (ERDA) respectively. Results show that $\mathrm{Cl}$ content in $\mathrm{Rw}$ and $\mathrm{Wd}$ is significantly higher than in other nominally anhydrous minerals from the upper mantle (olivine, pyroxene, garnet), with up to $490 \mathrm{ppm} \mathrm{Cl}$ in anhydrous Rw, and from 174 to $200 \mathrm{ppm} \mathrm{Cl}$ in hydrous Wd and up to 113 ppm Cl in hydrous Rw.
\end{abstract}

These results put constrains on the $\mathrm{Cl}$ budget of the deep Earth. Based on these results, we propose that the TZ may be a major repository for major halogen elements in the mantle, where $\mathrm{Cl}$ may be concentrated together with $\mathrm{H}_{2} \mathrm{O}$ and $\mathrm{F}$ (see Roberge et al., 2015). Assuming a continuous supply by subduction and a water-rich TZ, we use the concentrations measured in Wd (174 ppm Cl) and in Rw ( 106 ppm Cl) and we obtain a maximum value for the Cl budget for the bulk silicate Earth (BSE) of $15.1 \times 10^{22} \mathrm{~g} \mathrm{Cl}$, equivalent to $37 \mathrm{ppm} \mathrm{Cl}$. This value is larger than the $17 \mathrm{ppm} \mathrm{Cl}$ proposed previously by McDonough and Sun (1995) and evidences that the $\mathrm{Cl}$ content of the mantle may be higher than previously thought. Comparison of the present results with the budget calculated for F (Roberge et al., 2015) shows that while both elements abundances are probably underestimated for the bulk silicate Earth, their relative abundances are preserved. The BSE is too rich in F with respect to heavy halogen elements to be compatible with a primordial origin from chondrites CI-like (carbonaceous chondrites CC) material only. We thus propose a combination of two processes to explain these relative abundances: a primordial contribution of different chondritic-like materials, including EC-like (enstatite chondrites), possibly followed by a distinct fractionation of $\mathrm{F}$ during the Earth differentiation due to its lithophile behaviour compared to $\mathrm{Cl}, \mathrm{Br}$ and $\mathrm{I}$. 


\section{Introduction}

Halogen elements (fluorine $\mathrm{F}$, chlorine $\mathrm{Cl}$, bromine $\mathrm{Br}$, iodine I) are minor volatiles compared to hydrogen and carbon. Major halogens $\mathrm{F}$ and $\mathrm{Cl}$ have been mostly studied for their role in the shallowest Earth's reservoirs: lithosphere, crust, atmosphere, and hydrosphere, mostly because they are the most abundant halogens and because they have been shown to be strongly involved in volcanic and igneous processes. Indeed, $\mathrm{Cl}$ is an important constituent of volcanic fumaroles and plumes, and form individualized fluids such as brines and molten salts. These brines are strongly involved in hydrothermal systems and in ore forming processes (see the reviews after Pyle and Mather 2009; Shinohara 2009; Aiuppa et al., 2009). Cl is particularly used to trace igneous processes and ore-forming processes, and to track magmas from their genesis to their eruption $\mathrm{Cl}$ is known to affect magma properties (see Pyle and Mather, 2009), it is significantly degassed from subaerial volcanic activity (e.g. Aiuppa, 2009), and it can impact the stratosphere chemistry. $\mathrm{Cl}$ is enriched in sea water, it has been shown that oceanic subduction delivers fluids to the mantle through serpentinites related processes (serpentinization and deserpentinization), that are significantly Cl-rich (e.g. Ito et al., 1983; John et al., 2011; Kendrick et al., 2011), making this last one an important constituent in mantle metasomatism processes, that enriches the sources for arc magmatism (e.g. Tatsumi, 1989, Philippot et al., 1998; Scambelluri et al., 2004). Indeed magmas from subduction zones are among the most enriched in $\mathrm{Cl}$ (Ito et al., 1983; Straub and Layne, 2003; Kendrick et al., 2012).

During subduction, the interaction between seawater and rocks produces secondary minerals containing significant amounts of Cl (Ito et al., 1983; Pagé et al., 2016). It has thus been proposed that the subduction of oceanic lithospheric material at convergent plate boundaries would drive an annual global flux of 2.9-22 x 10 $12 \mathrm{~g}$ Cl to the Earth’s interior (John et al., 2011). It has also been proposed that a part of the subducted $\mathrm{Cl}$ would reach high depths in the mantle (>200 km) and would possibly enrich the sources for Ocean Island Basalts (Kendrick et al., 2015; Joachim et al., 2015). Cl is significantly present in ultrahigh pressure metamorphic rocks (Scambelluri et al., 2004; Ottolini and Fèvre, 2008; Pagé et al., 2016), in kimberlites (Kamenetsky et al., 2004), and in inclusions of saline brines in diamonds (Weiss et al., 2014). Recent studies show that $\mathrm{Cl}$ is present in olivine, pyroxene, and garnet: the highest contents of $\mathrm{Cl}$ are measured in minerals formed by metamorphic dehydration of serpentine, olivines and pyroxenes (up to $400 \mathrm{ppm} \mathrm{Cl,} \mathrm{Scambelluri} \mathrm{et} \mathrm{al.,} \mathrm{2004;} \mathrm{Ottolini} \mathrm{and} \mathrm{Fèvre,} \mathrm{2008).} \mathrm{In} \mathrm{natural}$ upper mantle nominally anhydrous minerals, the $\mathrm{Cl}$ contents are very low: up to $6.3 \mathrm{ppm}$ in 
olivine (Beyer et al., 2012). Partitioning experiments performed for natural compositions however demonstrate the capability of upper mantle minerals to be the Cl carriers: up to 148 ppm $\mathrm{Cl}$ in orthopyroxene, $17 \mathrm{ppm} \mathrm{Cl}$ in clinopyroxene, $13 \mathrm{ppm}$ in garnet, $5 \mathrm{ppm}$ in plagioclase, up to 170 ppm in olivine (Dalou et al., 2012). To our knowledge, there is currently no evidence about the presence of $\mathrm{Cl}$ in the transition zone and in the lower mantle. Recently we have suggested that a strong link connects the water global cycle and that of fluorine at depth (Crepisson et al., 2014; Roberge et al., 2015). We have proposed that the transition zone can be a major reservoir for fluorine (Roberge et al., 2015). It could be similar for Cl.

This study aims at constraining the possible deep storage and cycling of $\mathrm{Cl}$ through the determination of $\mathrm{Cl}$ potential contents in wadsleyite $(\mathrm{Wd})$ and ringwoodite $(\mathrm{Rw})$, the major minerals of the transition zone (TZ). We use these data to discuss the $\mathrm{Cl}$ content of the bulk silicate Earth.

\section{Materials and methods}

\subsection{Starting materials an experimental strategy}

The starting bulk composition was olivine Fogo with a slight excess of silica ((Mg+Fe)/Si atomic ratio $=1.75$ ), obtained with a mixture of (1) oxide powders of $\mathrm{MgO}, \mathrm{SiO}_{2}, \mathrm{FeO}$, or (2) natural Fogo olivine with $\mathrm{SiO}_{2}$ powder. $5 \mathrm{wt} \%$ of $\mathrm{Cl}$ was added to the mixture as crushed $\mathrm{NaCl}$ powder. $\mathrm{NaCl}$ was chosen as the source of $\mathrm{Cl}$ because it is enriched in sea water and in subducted oceanic floor. For experiments under hydrous conditions, $2 \mathrm{wt} \%$ of water was added as brucite $\mathrm{Mg}(\mathrm{OH})_{2}$, an amount close to the expected water solubility in wadsleyite and ringwoodite in the transition zone. Samples were synthesized in multi-anvil presses at LMV Clermont-Ferrand (France) and at the Bayerisches Geoinstitut of Bayreuth (Germany) following the procedure described in Frost et al. (2001) and Demouchy et al. (2005). Experiments were performed from 14 to $22 \mathrm{GPa}$ and from $1100^{\circ} \mathrm{C}$ to $1400^{\circ} \mathrm{C}$ during 0.5 to 9 hours, (Table 1 ). The samples were enclosed in Re, Pt or Au-Pd capsules. Temperatures were monitored with W3Re/W25Re thermocouples located at the top of the capsules. After the run, the experiments were quenched by switching off the electric power before decompression.

\subsection{Sample characterization}

The mineral assemblages were recovered, embedded in epoxy and mirror polished on one side. They were analyzed with Raman spectroscopy and scanning electron microscopy at first. The 
textures were investigated with a Zeiss Ultra 55 field emission scanning electron microscope (SEM) equipped with an Energy Dispersive X-Ray spectroscopy (EDX) system. Major elements compositions of wadsleyites and ringwoodites were subsequently measured by Electron Probe Micro Analysis (EPMA) on CAMECA-SX100 at CAMPARIS facility (UPMC, France). For these quantitative analyses, we used an acceleration voltage of $15 \mathrm{kV}$ and a beam current of $10 \mathrm{nA}$ with an $15 \mu \mathrm{m}$ defocused beam.

A thin section of ringwoodite sample was prepared with a Focus Ion Beam (FIB), using a gallium beam with a FEI Strata DB 235 at IEMN (Lille France). A transmission Electron Microscopy (TEM) study was performed on this FIB section at UMET, Lille (France) with a FEI Tecnai G2-20 twin operating at $200 \mathrm{kV}$.

Chlorine and hydrogen contents were measured using ion beam analysis, Particle Induced XRay Emission (PIXE) for $\mathrm{Cl}$ and Elastic Recoil Detection Analysis (ERDA) for $\mathrm{H}$ at the nuclear microprobe of the Laboratoire d'Etude des Eléments Légers (LEEL), CEA Saclay. Cl concentrations of the mineral phases $\mathrm{Wd}$ and $\mathrm{Rw}$ were obtained using incident beams of $3 * 3$ $\mu \mathrm{m}^{2}$ mapped on large areas (50*50 to $200 * 20 \mu \mathrm{m}^{2}$ ). The procedure is detailed in (Bureau et al., 2010; 2015). We used different incident beams $\left(\mathrm{H}^{+}\right.$and ${ }^{4} \mathrm{He}^{+}$from 1.7 to $\left.3 \mathrm{MeV}\right)$ in order to control the depth of investigation in the samples. With mineral phases a few tens of $\mu \mathrm{m}$ in size embedded in a quenched Cl-Si-rich glass (present at grain boundaries), compromise had to be found between energy and detection in order to avoid any chlorine contribution from glassy phase. Indeed the depths investigated by the ion beams depend both on the nature of the incident ion $\left(\mathrm{H}^{+},{ }^{4} \mathrm{He}^{+}\right)$and on the energy of the beam, (i.e. the highest the energy is the deepest is the investigation). For a San Carlos olivine, the depth of analysis for a proton beam is $50 \mu \mathrm{m}$ at 3 $\mathrm{MeV}$ and $25 \mu \mathrm{m}$ at $1.7 \mathrm{MeV}$. For one given energy, this depth is reduced when the incident ion is heavier than $\mathrm{H}^{+}$, at $2 \mathrm{MeV}$ the investigated depth of ${ }^{4} \mathrm{He}^{+}$is $6 \mu \mathrm{m}$.

Hydrogen (i.e. water) contents of Rw and Wd were measured using ERDA. We used a $3 \mathrm{MeV}$ ${ }^{4} \mathrm{He}^{+}$beam, following the protocol described in Raepsaet et al. (2008), Bureau et al. (2009) and Withers et al. (2012). Simultaneous $\mathrm{Cl}$ analysis were also performed by PIXE during ERDA. We scanned the beam on selected areas of the sample (from 30x30 to 150x100 $\mu^{2}$ ). Durations of analysis were chosen from 1800 to 7200 seconds. ERDA and PIXE were associated to simultaneous Rutherford Backscattering Spectrometry (RBS) measurements used to monitor the cumulated charge delivered to the sample during the acquisition (see Bureau et al., 2009). They also provided information on the matrix chemical composition of the samples. For all ion beam analysis, the software RISMIN (Daudin et al., 2003) was used to process the data by selecting the areas of interest in the chemical maps (see Fig. 1). It was particularly useful for 
154 the detection of NaCl-rich glasses (grain boundaries, cracks or surface contamination), which 155 would affect $\mathrm{H}$ and $\mathrm{Cl}$ contents. Once the areas were selected, ERDA spectra were processed 156 by using SIMNRA (Mayer et al., 1997) and PIXE spectra were processed by using the 157 GUPIXWIN software (Campbell et al., 2000). Analysis were cross-checked against: NIST 158 SRM610 glass (Rocholl et al., 1997), KE12 (pantellerite lava from Kenya, Metrich and 159 Rutherford, 1992), EtC3 (Cl-Br-I-bearing NaAlSi ${ }_{3} \mathrm{O}_{8}$ glass, Bureau et al., 2000). The sensitivity 160 (i.e. detection limit) with respect to $\mathrm{Cl}$ was of a few tens of ppm (30-40 at maximum) depending 161 on the conditions (beam energy, grain size, size of the selected areas).

162

163

164

165

166

167

168

169

170

171

172

173

174

175

176

177

178

179

180

181

182

183

184

\section{Results}

\subsection{Synthesized samples}

Ten samples were synthesized (see Table 1). Among these samples, two are volatile-free (no $\mathrm{H}_{2} \mathrm{O}$ and no $\mathrm{Cl}$ ), two are anhydrous (Cl-enriched but no $\mathrm{H}_{2} \mathrm{O}$ ), and six are $\mathrm{Cl}-\mathrm{H}_{2} \mathrm{O}$-enriched. Recovered mineralogical assemblages are described in Table 1 . They correspond to the mineral assemblages expected for the pressure and temperature conditions of the transition zone. The minerals are in equilibrium with a saline and silica-rich melts mostly present at grain boundaries. SEM shows that wadsleyite and ringwoodite phases exhibit subhedral or euhedral shapes and various crystal sizes (Fig. 1 and 2). In the runs performed at $14 \mathrm{GPa}$, we observe enstatite in agreement with literature (Inoue 1994; Inoue et al. 1995; Bolfan-Casanova 2000).

For runs performed at $22 \mathrm{GPa}$, stishovite ( $10 \mu \mathrm{m}$ in size) is found in equilibrium with ringwoodite (50-300 $\mu \mathrm{m}$ in size Fig. 2). For all experiments, crystals are embedded in a Si-NaCl-rich interstitial glass at grain boundaries which corresponds to the residual melt. No particular textural differences or abrupt increase in the relative proportion amount of quenched glasses are noted between experiments performed at different temperatures. Optical observation and SEM measurements show that the crystals are pure, inclusion-free ringwoodites and wadsleyites (no visible inclusions). Furthermore, a $100 \mathrm{~nm}$ thickness lamella of ringwoodite (sample \#S5553) was studied by transmission electron microscopy TEM (Figure 3). No Cl-rich or NaCl-rich micro or nano-inclusions have been observed. 
EMPA analyses show that the Cl-bearing wadsleyites and ringwoodites exhibit a Mg\# ratio

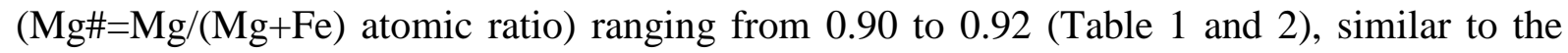
Earth’s mantle mineral assemblage.

\subsection{Chemical Characterization}

PIXE and ERDA mapping of large areas of the samples show that there is no chemical zoning with respect to $\mathrm{Cl}$ and $\mathrm{H}$ in the $\mathrm{Rw}$ and Wd crystals. About 5 to $20 \%$ in volume of NaCl-rich glasses are present in grain boundaries (Fig. 1). Enstatite is present at 5-10\% volume in all the samples containing wadsleyite and stishovite is present at about $5-15 \%$ volume in all the samples containing ringwoodite. A comparison between the different $\mathrm{Cl}$ contents obtained from each analytical conditions ( 3 and $1.7 \mathrm{MeV}, \mathrm{H}^{+}$and $\mathrm{He}^{+}$beams) shows that detection limits and uncertainties for $\mathrm{Cl}$ are dependent on the energy and ion source used (Table 2). The analyses performed with a $3 \mathrm{MeV}$ proton beam are the most sensitive to $\mathrm{Cl}$ contents but also to potential contamination (Cl-rich glasses located at grain boundary) because the depth of investigation is of about $50 \mu \mathrm{m}$. This depth is reduced to $25 \mu \mathrm{m}$ for a beam of $1.7 \mathrm{MeV}$, and to a few $\mu \mathrm{m}$ for a ${ }^{4} \mathrm{He}+$ beam of $3 \mathrm{MeV}$, but these two last conditions are much less sensitive. As the $\mathrm{Cl}$ contents determined at $3 \mathrm{MeV}$ were systematically higher than the measurements performed at $1.7 \mathrm{MeV}$ with a beam of $\mathrm{H}^{+}$or at $2 \mathrm{MeV}$ with a beam of ${ }^{4} \mathrm{He}^{+}$, we have only considered the measurements performed at $1.7 \mathrm{MeV}$ with a beam of $\mathrm{H}^{+}$and at 2 and $3 \mathrm{MeV}$ with a beam of ${ }^{4} \mathrm{He}^{+}$. The lowest $\mathrm{Cl}$ content analysed was of $60 \mathrm{ppm}$, a value higher than the detection limit. Two samples could not be analysed for $\mathrm{Cl}$ due to the very small size of the crystals.

Results show that $\mathrm{Cl}$ contents are significant, and range from $60 \pm 60$ to $200 \pm 48 \mathrm{ppm} \mathrm{Cl}$ for Wd and from $99 \pm 12$ to $490 \pm 33$ ppm Cl for Rw. Anhydrous Rw contain more Cl than hydrous $\mathrm{Rw}$, with a maximum of $490 \mathrm{ppm} \mathrm{Cl}$. Unfortunately, we failed analysing $\mathrm{Cl}$ in anhydrous $\mathrm{Wd}$ because crystals were too small. $\mathrm{Cl}$ contents of hydrous Wd are ranging from $60 \pm 60$ to $200 \pm$ $48 \mathrm{ppm} \mathrm{Cl}$ with corresponding water contents ranging from $917 \pm 15$ to $1659 \pm 14$ ppm $\mathrm{H}_{2} \mathrm{O}$. $\mathrm{Cl}$ contents of hydrous Rw are ranging from $99 \pm 12$ to $490 \pm 33 \mathrm{ppm} \mathrm{Cl}$ for water contents from $932 \pm 14$ to $4766 \pm 13$ ppm $\mathrm{H}_{2} \mathrm{O}$.

No relationship is observed between the temperature and both $\mathrm{Cl}$ and $\mathrm{H}_{2} \mathrm{O}$ contents (i.e. $\mathrm{OH}$ contents expressed as water equivalent concentrations, see Fig. 4 and 5). A slight decrease of $\mathrm{Cl}$ content with pressure may be suggested for hydrous samples. The incorporation of $\mathrm{Cl}$ in anhydrous Rw is higher than in hydrous Rw (Fig. 4 and 5). No significant dependency is found between the $\mathrm{Cl}$ content and $\mathrm{Mg} \#, \mathrm{FeO}, \mathrm{SiO}_{2}$ or $(\mathrm{Mg}+\mathrm{Fe}) / \mathrm{Si}$ atomic ratio. 

are about one order of magnitude lower than the previously observed solubility values from the literature (Bolfan-Casanova et al., 2000, Inoue et al., 1995, Demouchy et al., 2005) that reached 3 to $2.2 \mathrm{wt}$. \% respectively, at similar temperatures. In regard to the low $\mathrm{Cl}$ concentrations, we may exclude a competition between $\mathrm{OH}^{-}$and $\mathrm{Cl}^{-}$to enter in $\mathrm{Wd}$ and $\mathrm{Rw}$ structures. The significant reduction of $\mathrm{OH}$ incorporation cannot be compensated by an exchange between $\mathrm{OH}^{-}$ and $\mathrm{Cl}^{-}$. Similar low water contents have been found in NaF-doped wadsleyite and ringwoodite (Roberge et al., 2015). One sample: \#40_Cl, has been synthesized together with sample \#40_F from this previous study. This suggests that the same process could lower water content in Rw and Wd for both $\mathrm{F}$ and Cl-bearing samples.

We propose the sodium salts $\mathrm{NaCl}$ as $\mathrm{NaF}$ to be responsible of this behaviour (see Roberge et al., 2015). A coupled incorporation mechanism of $\mathrm{Na}^{+}$and $\mathrm{H}^{+}$in both $\mathrm{F}$ and Cl-rich $\mathrm{Wd}$ and Rw may be responsible of the low water content rather than a competitive effect between halogen elements and hydroxyl groups (Roberge et al., 2015). Stalder et al. (2008) have reported a strong decrease of hydrogen incorporation in pure synthetic enstatite at $2.5 \mathrm{GPa}$, $1150-1400^{\circ} \mathrm{C}$, and shown to be a function of the $\mathrm{NaCl}$ added in the starting materials. The low concentration of $\mathrm{OH}$ in enstatite is explained by a reduction of water activity in the fluid phase (melt or aqueous fluid) due to the presence of dissolved salt. In our experiments, the low water and possibly $\mathrm{Cl}$ content of the samples may be due to partitioning reaction between $\mathrm{Rw}$ and $\mathrm{Wd}$ and the Si-water and $\mathrm{NaCl}$-rich melt (up to $20 \%$ in volume) in equilibrium with the minerals during the experiments. If true, the $\mathrm{Cl}$ concentrations cannot be considered as solubilities. It would also explain why the water contents are so low (4766 ppm wt\% at maximum) compared to the initial amount of water (about 2 wt.\%). Additional partitioning experiments involving a Mg-rich peridotitic melt would be necessary to validate this hypothesis. As a first assumption, we will consider that the $\mathrm{Cl}$ contents measured in $\mathrm{Wd}$ and $\mathrm{Rw}$ are corresponding to the maximum contents expected in $\mathrm{Wd}$ and $\mathrm{Rw}$ in a transition zone where interstitial melt may be present (e.g. Toffelmier et Tyburczy, 2007; Schmandt et al. 2014).

\subsection{Cl versus $\mathrm{F}$ in ringwoodite and wadsleyite}

A comparison between $\mathrm{Cl}$ contents (this study) and comparable F contents in $\mathrm{Rw}$ and $\mathrm{Wd}$ (Roberge et al., 2015) at conditions relevant to the transition zone is presented in figure 6. All the samples are comparable as we have used alternatively $\mathrm{NaF}$ or $\mathrm{NaCl}$ salts as starting materials, and the same pressure and temperature conditions. We observe that $\mathrm{Cl}$ contents are 
253

lower than F contents by a factor of 3 in anhydrous ringwoodites. For hydrous Rw and Wd it is more variable, as $\mathrm{Cl}$ contents are ranging from $60 \pm 60$ to $200 \pm 48$ ppm when F contents vary from $186 \pm 19$ to $850 \pm 85$ ppm. The difference between F and Cl solubility’s in such chemical systems may reflect the difference in ionic size between $\mathrm{F}^{-}$and $\mathrm{Cl}^{-}$. It is likely $\mathrm{F}$ and $\mathrm{OH}$ share the same sites in olivine (Ol), wadsleyite and ringwoodite (Crepisson et al., 2014; Roberge et al., 2015), but this seems more unlikely for $\mathrm{Cl}$ which is larger than $\mathrm{F}$ and $\mathrm{OH}\left(\mathrm{Cl}^{-} 181 \mathrm{~nm}, \mathrm{OH}^{-}\right.$ $140 \mathrm{~nm}$ ). Fluorine incorporation in $\mathrm{Ol}, \mathrm{Wd}, \mathrm{Rd}$ is shown to be related to water incorporation (Crépisson et al., 2014, Roberge et al., 2015), but this is unclear for Cl. Indeed, similar Cl contents are observed in two samples of Rw with different water contents (Fig. 4). Further studies (i.e. FTIR spectroscopy) would be necessary to investigate into this direction. It is difficult to determine where $\mathrm{Cl}$ is incorporated in the crystal structure. The presence of $\mathrm{OH}$ defects in wadsleyite ( $\mathrm{Wd}$ ) and ringwoodite (Rw) have been investigated by coupling experimental observations to the modelling of infrared spectra (e.g, Blanchard et al. 2009; Blanchard et al., 2013) and provided insights into the crystal chemistry of $\mathrm{OH}$ in these minerals. The incorporation of $\mathrm{Cl}$ in $\mathrm{Rw}$ and $\mathrm{Wd}$ could be indirectly determined by studying the spectral signature of hydroxyl defects in NAMs, as for F-bearing hydrous olivines (Crépisson et al., 2014). As a first hypothesis, we suggest that in $\mathrm{Wd}$ and $\mathrm{Rw}, \mathrm{Cl}, \mathrm{F}$ and $\mathrm{OH}$ may occupy similar sites in the lattice, possibly mostly in association with Mg vacancies (as shown by Blanchard et al., 2013).

To summarize our major results: (1) the concentration of $\mathrm{Cl}$ in Wd and $\mathrm{Rw}$ is significant and can amount 490 ppm; (2) the concentration of $\mathrm{Cl}$ in $\mathrm{Wd}$ and $\mathrm{Rw}$ is 3 times smaller than compared to the concentration of $\mathrm{F}$ in the same phases synthesized in similar conditions; (3) anhydrous Rw are richer in both $\mathrm{Cl}$ and $\mathrm{F}$ than hydrous Rw; (4) the presence of water is not a pre-requisite to store $\mathrm{Cl}$ and $\mathrm{F}$ in these minerals. When present, water content is small, $\mathrm{Cl}$ and F contents may not be considered as solubility values for $\mathrm{Wd}$ and $\mathrm{Rw}$, but would rather reflect partitioning reactions with an interstitial melt.

\section{Discussion}

\subsection{Cl storage in the mantle Transition Zone's wadsleyite and ringwoodite phases}

It is now recognized that the TZ is hydrated at least locally as shown by recent studies: (1) the significant water content of a hydrous ringwoodite trapped in a natural diamond exhumed from 
the transition zone (Pearson et al., 2014), (2) geophysical data (e.g. Huang et al., 2005). We consider hydrous $\mathrm{Wd}$ and $\mathrm{Rw}$ in the following sections: according to our measurements, ringwoodite contains $60 \pm 60 \mathrm{ppm} \mathrm{Cl}$ and $917 \pm 15 \mathrm{ppm} \mathrm{H}_{2} \mathrm{O}$; wadsleyite can take up to $200 \pm$ $48 \mathrm{ppm} \mathrm{Cl}$ and $1115 \pm 14 \mathrm{ppm} \mathrm{H}_{2} \mathrm{O}$. Such significant amounts are not surprising if we compare with the incorporation of fluorine in Wd and Rw (665 to 1045 ppm F, up to 956 ppm $\mathrm{H}_{2} \mathrm{O}$ in Wd and 186 to 1235 ppm F, up to 1404 ppm $\mathrm{H}_{2} \mathrm{O}$ in Rw, see Roberge et al., 2015). Furthermore, the range of water contents measured in Cl-rich $\mathrm{Rw}$ and $\mathrm{Wd}$ are consistent with what is predicted for the transition zone i.e. 1000-2000 ppm (Huang et al., 2005) and 2000 ppm - 2 wt.\% (Bercovici and Karato, 2003).

We assume, that no significant amounts of $\mathrm{Cl}$ are dissolved in the other minor mineral phases of the TZ. We use an average pyrolitic composition with modal abundances of $60 \%$ wt. wadsleyite from 410 to $520 \mathrm{~km}$ and $60 \%$ wt. ringwoodite from 520 to $660 \mathrm{~km}$ with addition of 40\%wt. of garnet and clinopyroxene from 410 to $660 \mathrm{~km}$ (Ringwood, 1975), and with the $\mathrm{Cl}$ contents of hydrous Fo90 wadsleyite and ringwoodite (174 ppm and 106 ppm respectively). An upper bound for $\mathrm{Cl}$ storage in the transition zone would be of $3 \times 10^{22} \mathrm{~g} \mathrm{Cl}$, corresponding to 80 ppm Cl. Wd and the Rw could be major carriers of the deep $\mathrm{Cl}$, and should be thus taken into account for the Earth budget of this element.

In order to explain a chemical contrast between low water contents in the upper mantle with about 142 ppm water (Saal et al., 2002) and assuming a water-rich transition zone (having 0.22\% wt\% water), Bercovici and Karato (2003) have proposed the transition zone water-filter model. In this model, the downwelling fluxes driven by slabs into the transition zone and deeper lower mantle trigger a passive upwelling flow. At $410 \mathrm{~km}$, this upwelling flow would rises out of the high-water-solubility transition zone with the transition of $\mathrm{Wd}$ to olivine together with a water release, as olivine has a lower solubility with respect to water than Wd (Bolfan-Casanova et al., 2000). Such a phase transition would then favour the formation of a melt layer overlying the transition zone, having a density higher than the solid phase. This layer would act as a filter, and would maintain a chemical contrast for trace and volatile elements between a depleted upper mantle and an enriched upper transition zone (Bercovici and Karato, 2003), it would permit a significant storage of $\mathrm{Cl}, \mathrm{F}$ and $\mathrm{H}_{2} \mathrm{O}$ in the transition zone.

\subsection{How much $\mathrm{Cl}$ in the Bulk Silicate Earth?}


320 Based on the average Cl contents in Mid Ocean Ridge Basalts, McDonough and Sun (1995) 321 have estimated an abundance of $17 \mathrm{ppm} \mathrm{Cl}$ for the bulk silicate Earth. We have calculated the 322 maximum $\mathrm{Cl}$ storage of the bulk silicate Earth, by adding the $\mathrm{Cl}$ contribution for each reservoir. 323 Results are summarized in the figure 7, for $\mathrm{Cl}$ (this study) and for F (Roberge et al., 2015).

324 For the shallow reservoirs we assume the $\mathrm{Cl}$ crust contribution (ocean, evaporite, brine and 325 crustal rock abundances) to be $5.8 \times 10^{22} \mathrm{~g}$ (Sharp et al., 2013); we have used the value of $1 \mathrm{ppm}$ 326 Cl from Saal et al., (2002) to represent the depleted shallow upper mantle. For the transition 327 zone, we assumed a hydrous $\mathrm{TZ}$ enriched in $\mathrm{Cl}$, due to a continuous supply by subduction, we 328 obtained a maximum storage of $3 \times 10^{22} \mathrm{~g}$ of $\mathrm{Cl}$, corresponding to the average concentration of $80 \mathrm{ppm}$. For the lower mantle we used the value of $21 \mathrm{ppm} \mathrm{Cl}$ calculated from Ocean Island Basalts compositions by Kovalenko et al. (2006), assumed to be representative of the primitive mantle. The resulting Bulk silicate Earth content for chlorine would then be of $15 \times 10^{22} \mathrm{~g}$, corresponding to a value of $37 \mathrm{ppm} \mathrm{Cl}$, with a contribution of $20 \%$ from the transition zone (Figure 7). No significant change of the $\mathrm{F} / \mathrm{Cl}$ ratio is observed (0.68, McDonough and Sun, 1995, 0.62, this study). This estimate of $37 \mathrm{ppm} \mathrm{Cl}$ in the bulk silicate Earth is twice the previous one of $17 \mathrm{ppm}$ (McDonough and Sun, 1995), it shows that the Earth's budget of $\mathrm{Cl}$ and F could be largely underestimated.

\subsection{What about the origin of chlorine and fluorine of the Earth?}

The origin of the volatile elements for the Earth is still highly debated today, but most of the models (e.g. Albarède, 2009; Javoy et al., 2010; Marty et al., 2012) propose that they originated from a cosmochemical reservoir that also sourced the parent bodies of primitive meteorites. The absence of correct condensation temperatures (Lodders, 2003) for both $\mathrm{Cl}$ and $\mathrm{F}$ makes difficult the calculation of the predicted abundances for $\mathrm{Cl}$ and $\mathrm{F}$ in an Earth accreted from any chondritic materials. For water, a chondritic origin is preferred because the terrestrial and chondritic D/H ratios are similar (see Marty and Yokochi, 2006 and references therein). Among the primitive meteorites, carbonaceous chondrites CC are the most popular candidates to reflect the Earth's volatile source. Marty (2012) shows that a later contribution of $2 \pm 1 \%$ of carbonaceous chondrite from the CI species to a dry proto-Earth would be consistent with the Earth atmophile elements (C, H, N, noble gases) and is in agreement with heavy halogen elements (Cl, Br, I) contents determined by McDonough and Sun (1995). However, according 
to Marty (2012), a contribution of $17 \%$ of CI would be necessary to explain the F abundance from McDonough and Sun (1995). A greater halogen content such as the one presented here cannot be easily reconciled with an Earth only built by homogeneous accretion of CI carbonaceous chondrite material. Alternatively, enstatite chondrites (EC) are F-enriched (i.e. $\mathrm{F} / \mathrm{Cl}=2.77$ to 1.16 , Rubin and Choi, 2009), with a heavy halogen element content similar to those of CI (Rubin and Choi, 2009). EC were already proposed to be the building material for the Earth (e.g. Javoy, 1995), based on the isotopic signature of oxygen and nitrogen. However, EC are water-poor, the Earth's Si isotopic compositions cannot be explained from a coreformation scenario from a BSE having a EC's composition, and the Mg/Si ratio of the upper mantle differs too much from the EC's. It is also proposed that the Earth was built from the mixing of a number of chondritic like end-members having different volatile compositions (Marty and Yokochi, 2006), including EC. The mixing of different volatile-rich late veneers is however not sufficient to explain the depletion of $\mathrm{Cl}$ (and also $\mathrm{Br}$ and $\mathrm{I}$ ) compared to $\mathrm{F}$ of the BSE, which may reflect processes that have occurred during differentiation, after volatile acquisition (primitive or from a late veneer). Fluorine has a lithophile character compared to $\mathrm{Cl}, \mathrm{Br}, \mathrm{I}$ (McDonough and Sun, 1995). F content is greater than $\mathrm{Cl}$ content in both Wd and Rw. During the magma ocean crystallization, F could have been stored in mantle minerals whereas the heavier halogen elements may have been partially lost from the magma by devolatilization, a loss possibly due to their hydrophilic affinity (Sharp and Draper, 2013; Bureau et al., 2015). As long as the actual $\mathrm{Cl}$ and $\mathrm{F}$ budget of the Earth will remain un-determined, the origin of volatile elements of the Earth will remain an open question.

\section{CONCLUSION}

The experimental determination of the $\mathrm{Cl}$ concentration in hydrous wadsleyite and ringwoodite shows that they can be major carriers for $\mathrm{Cl}$ in the deep Earth. The transition zone can thus be a deep significant repository for $\mathrm{Cl}$. $\mathrm{Cl}$ contents are lower by a factor of 3 than those observed by Roberge et al. (2015) for F. For both $\mathrm{Cl}$ and $\mathrm{F}$, the presence of water lowers their concentrations in Rw and Wd, but this storage capacity remains significant. It is thus likely that both halogen elements are stored with water in the Earth's transition zone with a maximum content of $80 \mathrm{ppm} \mathrm{Cl}$.

Nominally anhydrous minerals are the main $\mathrm{Cl}$ carriers in the mantle at least down to $660 \mathrm{~km}$ depth. Although it has been shown that F is strongly associated to water through incorporation 
mechanisms in the NAMs, $\mathrm{Cl}$ incorporation in silicate minerals lattice is not so clear and would deserve to be further studied. Assuming a continuous supply from subduction recycling, we calculate a maximum BSE content for chlorine of $15 \times 10^{22} \mathrm{~g} \mathrm{Cl}$, corresponding to $37 \mathrm{ppm} \mathrm{Cl}$ is proposed. The corresponding global budget for $\mathrm{Cl}$ is twice the value proposed by $\mathrm{McDonough}$ and Sun (1995). In the light of these experimental results for both $\mathrm{Cl}$ and $\mathrm{F}$, we propose that the modern relative abundances of $\mathrm{Cl}$ and $\mathrm{F}$ may result from the combination of two processes during the Earth's accretion: a mixing contribution of CC and EC chondritic-like materials (required to generate the $\mathrm{F}$ enrichment compared to $\mathrm{Cl}, \mathrm{Br}, \mathrm{I}$ ); possibly followed by a fractionation of $\mathrm{F}$ from other halogen elements during the Earth's differentiation, whereas most of the $\mathrm{F}$ being stored in mantle minerals when part of the heavy halogens would have been preferentially partitioned in the magma ocean, degassed and lost.

\section{Acknowledgments}

We acknowledge Daniel J. Frost and the BGI’s Staff, particularly H. Schulze, for their constant availability and precious help with the high pressure experiments performed in Bayreuth. We also thank the LMV's staff for their help during the experiments carried out in Clermont Ferrand. We are grateful to $\mathrm{H}$. Khodja and the the LEEL staff during the analysis of the samples using the nuclear microprobe. We warmly thank J. C. Boulliard from the mineralogical collection of UPMC, I. Estève for her assistance during SEM analysis, O. Beyssac for access to the Raman spectrometer; and CAMPARIS staff for EMPA analyses.

We acknowledge John P. Brodholt, Editor for Earth and Planetary Sciences Letters, who has handled the manuscript. The manuscript was improved thanks to the detailed reviews of two anonymous reviewers.

The SEM of IMPMC which is supported by Région Ile de France Grant SESAME 2006 NOI07-593/R, INSU-CNRS, INP-CNRS, UPMC, and by the French National Research Agency (ANR) Grant ANR-07-BLAN-0124-01. The FIB facility was supported by the French RENATECH network, and the TEM national facility in Lille (France) was supported by the Conseil Regional du Nord-Pas de Calais, the European Regional Development Fund (ERDF), and the Institut National des Sciences de l'Univers (INSU, CNRS). The national high-pressure facility multi-anvil presses, MLV Clermont-Ferrand, is also supported by INSU, CNRS. The 
422 present study was funded by the EGIDE PHC PROCOPE project 26673WC to H.B. and DAAD 423 PROCOPE project 54366326 to D.J.Frost.

424

425 
427 Aiuppa, A., Baker, D.R., and Webster, J.D. (2009). Halogens in volcanic systems. Chem. Geol. 428 263, 1-18.

429 Albarède F. (2009) Volatile accretion history of the terrestrial planets and dynamic 430 implications, Nature, vol. 461, no 7268, p. 1227-1233.

431

432

433

434

435

436

437

438

439

440
Bercovici, D., and Karato, S. (2003). Whole-mantle convection and the transition-zone water filter. Nature 425, 39-44.

Beyer, C., Klemme, S., Wiedenbeck, M., Stracke, A., and Vollmer, C. (2012). Fluorine in nominally fluorine-free mantle minerals: Experimental partitioning of $\mathrm{F}$ between olivine, orthopyroxene and silicate melts with implications for magmatic processes. Earth Planet. Sci. Lett. 337-338, 1-9.

Blanchard, M., Balan, E., and Wright, K. (2009). Incorporation of water in iron-free ringwoodite: A first-principles study. Am. Mineral. 94, 83-89.

Blanchard, M., Roberge, M., Balan, E., Fiquet, G., and Bureau, H. (2013). Infrared signatures of OH-defects in wadsleyite: A first-principles study. Am. Mineral. 98, 2132-2143.

Bolfan-Casanova, N., Keppler, H., and Rubie, D.C. (2000). Water partitioning between nominally anhydrous minerals in the MgO-SiO2-H2O system up to $24 \mathrm{GPa}$ : implications for the distribution of water in the Earth's mantle. Earth Planet. Sci. Lett. 182, 209-221.

Bureau, H., Keppler, H., Métrich, N. (2000) Volcanic degassing of bromine and iodine: experimental fluid/melt partitioning data and applications to stratospheric chemistry, Earth and Planetary Science Letters, 183, 51-60.

Bureau, H., Raepsaet, C., Khodja, H., Carraro, A., and Aubaud, C. (2009). Determination of hydrogen content in geological. samples using elastic recoil detection analysis (ERDA). Geochim. Cosmochim. Acta 73, 3311-3322.

Bureau, H., Auzende, A.-L., Marocchi, M., Raepsaet, C., Munsch, P., Testemale, D., Mézouar, M., Kubsky, S., Carrière, M., Ricolleau, A., Fiquet, G. (2015) The Volcanic degassing of Iodine, Geochimica et Cosmochimica Acta, 173, 114-125.

Campbell, J.L., Hopman, T.L., Maxwell, J.A., and Nejedly, Z. (2000). The Guelph PIXE software package III: Alternative proton database. Nucl. Instrum. Methods Phys. Res. Sect. B Beam Interact. Mater. At. 170, 193-204.

Crépisson, C., Blanchard, M., Bureau, H., Sanloup, C., Withers, A.C., Khodja, H., Surblé, S., Raepsaet, C., Béneut, K., Leroy, C., et al. (2014). Clumped fluoride-hydroxyl defects in forsterite: Implications for the upper-mantle. Earth Planet. Sci. Lett. 390, 287-295.

Dalou, C., Koga, K.T., Shimizu, N., Boulon, J., and Devidal, J.-L. (2012). Experimental determination of $\mathrm{F}$ and $\mathrm{Cl}$ partitioning between lherzolite and basaltic melt. Contrib. Mineral. Petrol. 163, 591-609. 
Daudin, L., Khodja, H., and Gallien, J.-P. (2003). Development of "position-charge-time" tagged spectrometry for ion beam microanalysis. Nucl. Instrum. Methods Phys. Res. Sect. B Beam Interact. Mater. At. 210, 153-158.

Demouchy, S., Deloule, E., Frost, D.J., and Keppler, H. (2005). Pressure and temperaturedependence of water solubility in Fe-free wadsleyite. Am. Mineral. 90, 1084-1091.

Frost, D.J., Langenhorst, F., van Aken, P.A. (2001). Fe-Mg partitioning between ringwoodite and magnesiowüstite and the effect of pressure, temperature and oxygen fugacity. Phys. Chem. Minerals 28, 455-470.

Huang, X., Xu, Y., and Karato, S. (2005). Water content in the transition zone from electrical conductivity of wadsleyite and ringwoodite. Nature 434, 746-749.

Ito, E., Harris, D.M., and Anderson Jr., A.T. (1983). Alteration of oceanic crust and geologic cycling of chlorine and water. Geochim. Cosmochim. Acta 47, 1613-1624.

Javoy, M. (1995). The integral enstatite chondrite model of the Earth. Geophys. Res. Lett. 22, 2219-2222.

Joachim, B., Pawley, A., Lyon, I.C., Marquardt, K., Henkel, T. Clay, P.L., Ruzié, L., Burgess, R., Ballentine, C.J. (2015) Experimental partitioning of $\mathrm{F}$ and $\mathrm{Cl}$ between olivine, orthopyroxene and silicate melt at Earth's mantle conditions. Chem. Geol. 416, 65-78.

John, T., Scambelluri, M., Frische, M., Barnes, J.D., and Bach, W. (2011). Dehydration of subducting serpentinite: Implications for halogen mobility in subduction zones and the deep halogen cycle. Earth Planet. Sci. Lett. 308, 65-76.

Kendrick, M.A., Scambelluri, M., Honda, M., Phillips, D. (2011) High abundances of noble gas and chlorine delivered to the mantle by serpentinite subduction. Nat. Geosci. 4, 807-812.

Kendrick, M.A., Woodhead, J.D., and Kamenetsky, V.S. (2012). Tracking halogens through the subduction cycle. Geology 40, 1075-1078.

Kendrick, M.A., Jackson, M.G., Hauri, E.H., Phillips (2015). The halogen (F, Cl, Br, I) and $\mathrm{H}_{2} \mathrm{O}$ systematics of Samoan lavas: Assimilated-seawater, EM2 and high- ${ }^{3} \mathrm{He} /{ }^{4} \mathrm{He}$ components. Earth and Planet. Sci. Lett. 410, 197-209.

Kovalenko, V.I., Naumov, V.B., Girnis, A.V., Dorofeeva, V.A., and Yarmolyuk, V.V. (2006). Composition and chemical structure of oceanic mantle plumes. Petrology 14, 452-476.

Marty, B., Yokochi, R., (2006). Water in the Early Earth. Reviews in Mineralogy and Geochemistry 62, 421-450.

Marty, B. (2012). The origins and concentrations of water, carbon, nitrogen and noble gases on Earth. Earth Planet. Sci. Lett. 313-314, 56-66.

Mayer, M., 1997. SIMNRA User's Guide. Report IPP 9/113, Max-Planck-Institut für Plasmaphysik, Garching, Germany.

McDonough, W.F., and Sun, S. -s. (1995). The composition of the Earth. Chem. Geol. 120, 223-253. 

Silicic Melts. Geochim. Cosmochim. Acta 56, 607-616.

506 Ottolini, L.P., and Fèvre, B.L. (2008). SIMS analysis of chlorine in metasomatised upper507 mantle rocks. Microchim. Acta 161, 329-336.

508 Pagé, L., Hattori, K., de Hoog, J.C.M., Okay, A.I. (2016). Halogen (F, Cl, Br, I) bahaviour in 509 subducting slabs: a study in lawsonite blueshist in Western Turkey. Earth and Planet. Sci. Let. 510 442, 133-142.

Pearson, D.G., Brenker, F.E., Nestola, F., McNeill, J., Nasdala, L., Hutchison, M.T., Matveev, 513 indicated by ringwoodite included within diamond. Nature 507, 221-224.

Philippot, P., Agrinier, P., and Scambelluri, M. (1998). Chlorine cycling during subduction of altered oceanic crust. Earth Planet. Sci. Lett. 161, 33-44.

Pyle D. M. and Mather T. A., 2009. Halogens in igneous processes and their fluxes to the atmosphere and oceans from volcanic activity: A review, Chem. Geol., vol. 263, n 1-4, p. $110-$ 121.

Ringwood, A.E. (1975). Composition and Petrology of the Earth’s Mantle. McGraw-Hill New York.

Roberge, M., Bureau, H., Bolfan-Casanova, N., Frost, D.J., Raepsaet, C., Surblé, S., Khodja, H., Auzende, A.L. , Fiquet, G. (2015). Is the the transition zone a deep reservoir for fluorine? Earth and planet. Sci. Lett. 429, 25-32.

Rocholl, A.B.E., Simon, K., Jochum, K.P., Bruhn, F., Gehann, R., Kramar, U., Luecke, W., AAS and PIXE. Geostand. Newsl. 21, 101-114.

529 Rudnick R.L., Gao S. (2003). Composition of the continental crust. Treatrise on Geochemistry $530 \quad 3: 1-64$.

531 Rubin, A.E., and Choi, B.-G. (2009). Origin of Halogens and Nitrogen in Enstatite Chondrites. 532 Earth Moon Planets 105, 41-53.

Saal, A.E., Hauri, E.H., Langmuir, C.H., and Perfit, M.R. (2002). Vapour undersaturation in primitive mid-ocean-ridge basalt and the volatile content of Earth's upper mantle. Nature 419, 535 451-455.

Scambelluri, M., Müntener, O., Ottolini, L., Pettke, T.T., and Vannucci, R. (2004). The fate of $\mathrm{B}, \mathrm{Cl}$ and $\mathrm{Li}$ in the subducted oceanic mantle and in the antigorite breakdown fluids. Earth Planet. Sci. Lett. 222, 217-234.

Sharp, Z.D., Draper, D.S. (2013) The Chlorine abundance of the Earth: Implications for a habitable planet. Earth and Planet. Sci. Lett. 369, 71-77. 
544 Stalder, R., Kronz, A., and Simon, K. (2008). Hydrogen incorporation in enstatite in the system $545 \mathrm{MgO}-\mathrm{SiO}_{2}-\mathrm{H}_{2} \mathrm{O}-\mathrm{NaCl}$. Contrib. Mineral. Petrol. 156, 653-659.

546 Straub, S.M., and Layne, G.D. (2003). The systematics of chlorine, fluorine, and water in Izu 547 arc front volcanic rocks: Implications for volatile recycling in subduction zones. Geochim. 548 Cosmochim. Acta 67, 4179-4203.

549 Tatsumi Y. (1989). Migration of fluid phases and genesis of basalt magmas in subduction zones. 550 J. Geophys. Res. 94, 4697-4707.

551

552

553

554

555

556

557

558

559

560

561

562
Toffelmier, D.A., and Tyburczy, J.A. (2007). Electromagnetic detection of a 410-km-deep melt layer in the southwestern United States. Nature, 447, 991-994.

Weiss Y., Kiflawi I., Davies N., Navon O. (2014), High-density fluids and the growth of monocrystalline diamonds. Geochimica et Cosmochimica Acta 141, 145-159.

Withers, A.C., Bureau, H., Raepsaet, C., and Hirschmann, M.M. (2012). Calibration of infrared spectroscopy by elastic recoil detection analysis of $\mathrm{H}$ in synthetic olivine. Chem. Geol. 334, 92-98. 


\section{Figure 1:}

Sample \#S5553 $\left(1100^{\circ} \mathrm{C}\right.$ and $\left.20 \mathrm{GPa}\right)$ : hydrous Cl-bearing ringwoodite synthesized at $1100^{\circ} \mathrm{C}$ and 20 GPa.

A. PIXE spectrum of one Rw crystal $\mathrm{Cl}$ and Fe Kalpha and Kbeta rays respectively at $2.62-2.81$ and $6.40-7.05 \mathrm{KeV}$ are labelled on the spectrum.

B. SEM photography of sample \#S5553. Ringwoodite (in light grey), the largest grain sizes are of more than $70 \mu \mathrm{m}$; stishovite is not present on this section, a Cl-rich melt is visible in grain boundaries. The white square is corresponding to the total map analysed with PIXE.

C. PIXE elemental map for iron.

D. PIXE elemental map for $\mathrm{Cl}$.

A pure ringwoodite crystal is selected using the combination of the SEM photography with the elemental compositions (e.g. iron C and chlorine D) in order to avoid any chemical contamination from intersticial melt. This crystal is represented by the black shape in the SEM photography, and by the white shape in the chemical maps $C$ and $D$. This area of interest (one ringwoodite crystal) is used to generate the PIXE spectrum presented in A.

\section{Figure 2:}

SEM photography of A) S5551 (anhydrous Cl-bearing ringwoodite synthesized at $1100^{\circ} \mathrm{C}$ and $20 \mathrm{GPa}$ ). $\mathrm{Rw}$ ringwoodite (in light grey), the grain sizes are of about $15 \mu \mathrm{m}$; St stishovite crystals are in dark grey with $6 \mu \mathrm{m}$ medium size, intergranular glass is dark B) H3697 (hydrous Cl-bearing ringwoodite synthesized at $1400^{\circ} \mathrm{C}$ and $22 \mathrm{GPa}$ ), Rw ringwoodite (in light grey), the grain sizes are of about $20 \mu \mathrm{m}$; St stishovite crystals are in dark grey, intergranular glass is dark.

\section{Figure 3}

TEM analysis of a ringwoodite thin section of about $100 \mathrm{~nm}$ thickness (prepared by focused ion beam) for transmission electron microscopy study, from sample \#S5553 (20 GPa, $1100^{\circ} \mathrm{C}, 240 \mathrm{~min}$.) containing 99 ppm wt. $\mathrm{Cl}$ and 4766 ppm wt. $\mathrm{H}_{2} \mathrm{O}$.

A: Scanning Transmission Electron Microscopy (STEM) bright field micrograph of the ringwoodite showing the only heterogeneities found in the sample.

$\mathrm{B}$ and C: EDX analysis of $\mathrm{Na}$ and $\mathrm{Cl}$ contents within the green rectangle in $\mathrm{A}\left(1800 \times 1100 \mathrm{~nm}^{2}\right)$, they show that heterogeneities are not related to any $\mathrm{Cl}$-rich or $\mathrm{NaCl}$-rich inclusions, and emphasize the uniform distribution.

\section{Figure 4:}

$\mathrm{Cl}$ content in ppm wt. versus temperature in ${ }^{\circ} \mathrm{C}$. No significant effect of the temperature on the $\mathrm{Cl}$ content is seen.

Legend: white squares: hydrous wadsleyite, white triangles: hydrous ringwoodite. black triangle: anhydrous ringwoodite.

\section{Figure 5:}

$\mathrm{Cl}$ content in ppm wt. versus water contents in ppm wt. The highest $\mathrm{Cl}$ concentration is corresponding to anhydrous ringwoodite. $\mathrm{Cl}$ content seems to slightly decrease with water content, but we notice that for a same $\mathrm{Cl}$ content of about $100 \mathrm{ppm}$ wt., the water content is ranging from 932 to $4766 \mathrm{ppm}$ in ringwoodite. It would mean that the Cl content is not affected by water for such low amounts. Same legend than Fig 4.

\section{Figure 6:}

$\mathrm{Cl}$ and $\mathrm{F}$ concentrations measured in $\mathrm{Wd}$ and $\mathrm{Rw}$, synthesized using the same experimental protocol and from $\mathrm{NaCl}$ and $\mathrm{NaF}$ sources. Data from this study and from Roberge et al. (2015). Assuming a hydrous transition zone, ranges of potential $\mathrm{Cl}$ and $\mathrm{F}$ concentrations in $\mathrm{Ol}, \mathrm{Wd}, \mathrm{Rw}$ are proposed. 
617 Legend: white squares: hydrous wadsleyite, white triangles: hydrous ringwoodite, white circles: 618 olivines, black triangles: anhydrous ringwoodite, black square: anhydrous wadsleyite.

\section{Figure 7}

State of the art of the $\mathrm{Cl}$ and $\mathrm{F}$ budgets of the Earth, assuming a continuous supply by subduction of the TZ with respect to $\mathrm{Cl}$ and F. Reservoirs: crust (Rudnick and Gao, 2003); upper mantle without TZ (Saal, 2002); TZ, Cl this study, F (Rogerge et al., 2015); lower mantle, Cl (Beyer et al., 2012), F (Kovalenko

626 et al., 2006). Degassing Fluxes are expressed in $\mathrm{HCl}\left(4.310^{12} \mathrm{~g} / \mathrm{yr}\right)$ and $\mathrm{HF}\left(0.510^{12} \mathrm{~g} / \mathrm{yr}\right)$, they are 627 corresponding to $4.1810^{12} \mathrm{~g} / \mathrm{yr} \mathrm{Cl}$ and $0.4710^{12} \mathrm{~g} / \mathrm{yr} \mathrm{F}$ respectively, data are from Pyle and Mather (2009); subducted fluxes are from Straub and Layne (2003) and John et al. (2011).

630

631

632 
633 Figure 1:

634
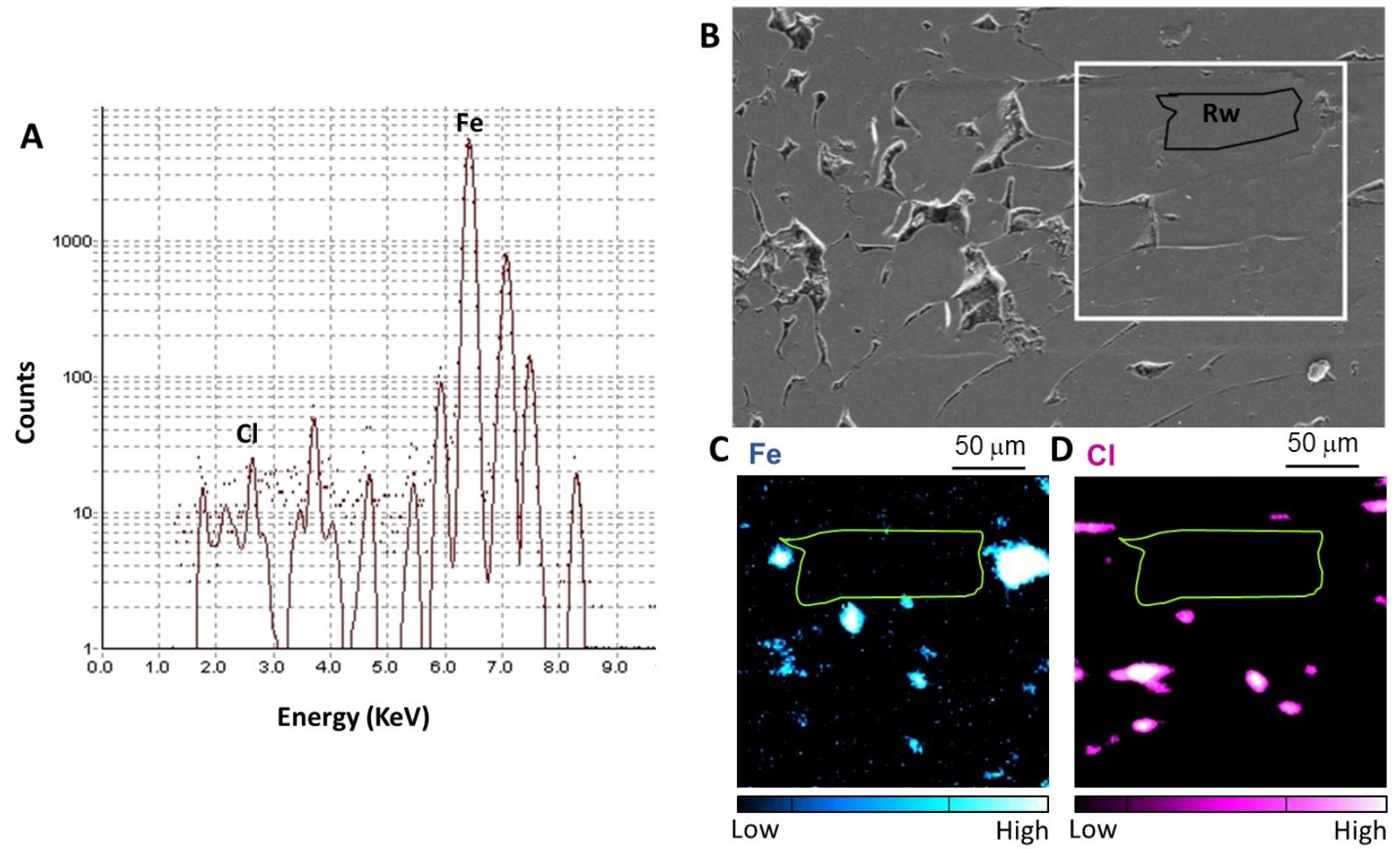

635

636

637

638 
639 Figure 2:

640
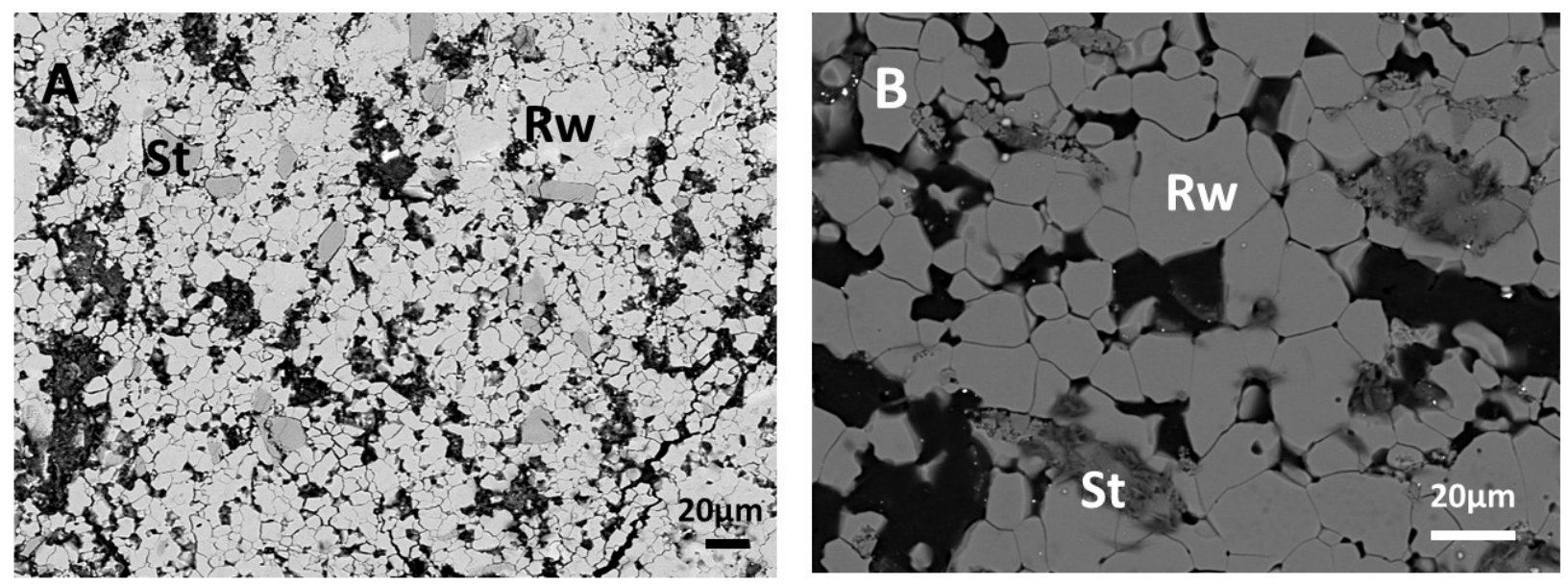

641

642

643

644

645

646

647

648

649

650

651

652

653 
654 Figure 3:

655

656

657

658

659 
660

661

662

663

664

665

666

667

668

669

670

671

672

673

Figure 4:

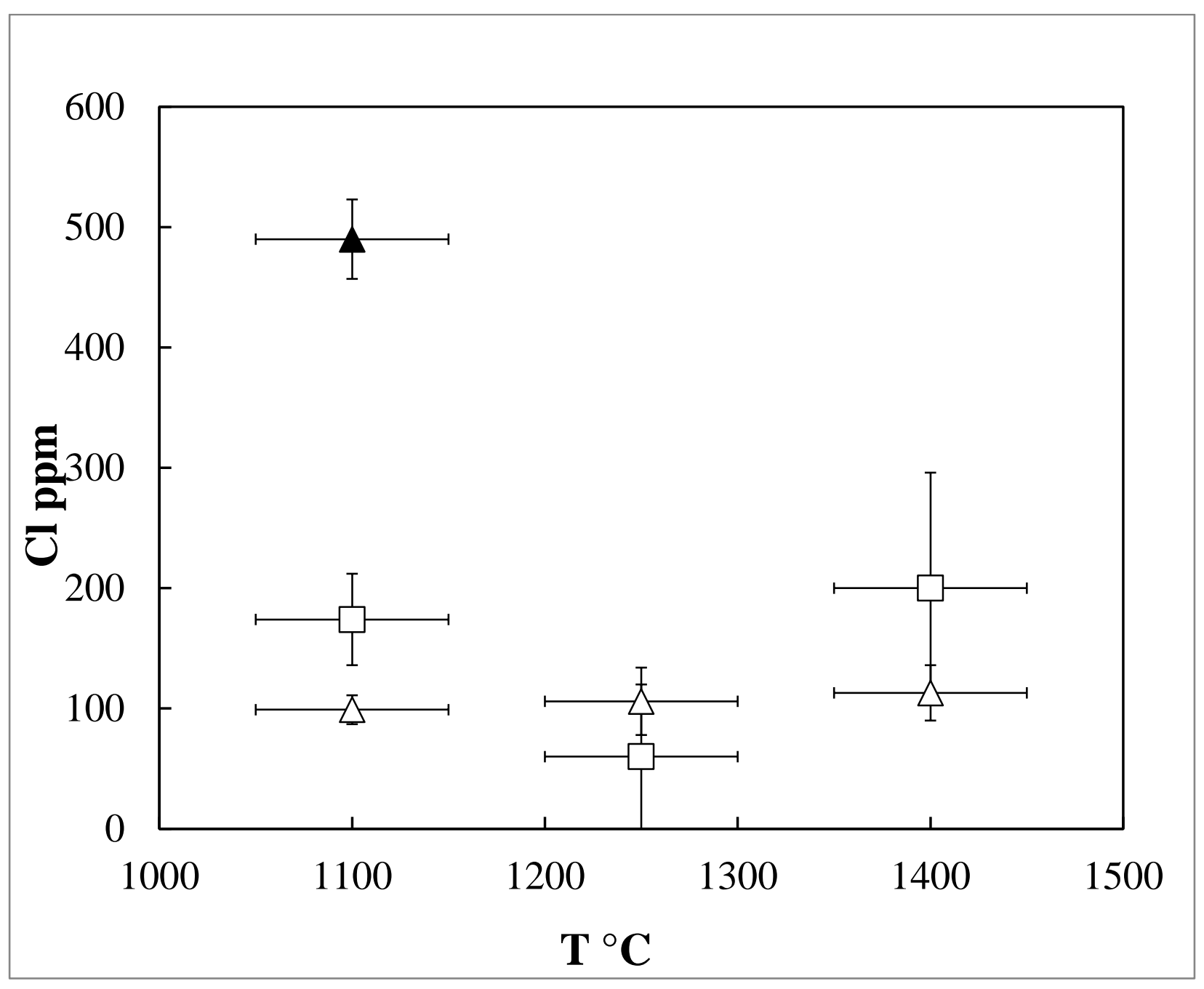


674 Figure 5:

675

676

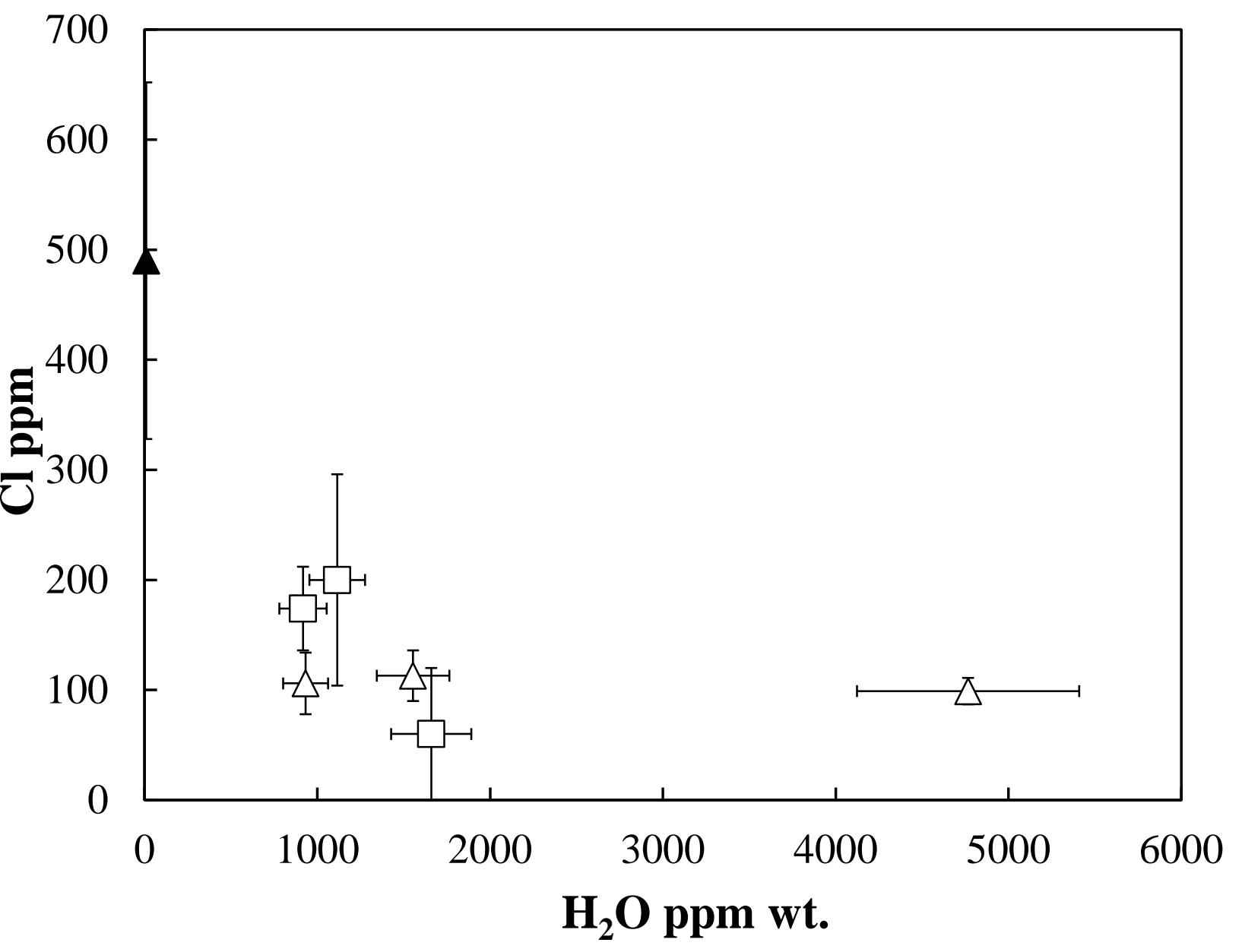


678

679

680

681

682

683

684

685

686

687

688

689

690

691

692

693

694

695

696

697

698

699

700

701

702

703

704

Figure 6:

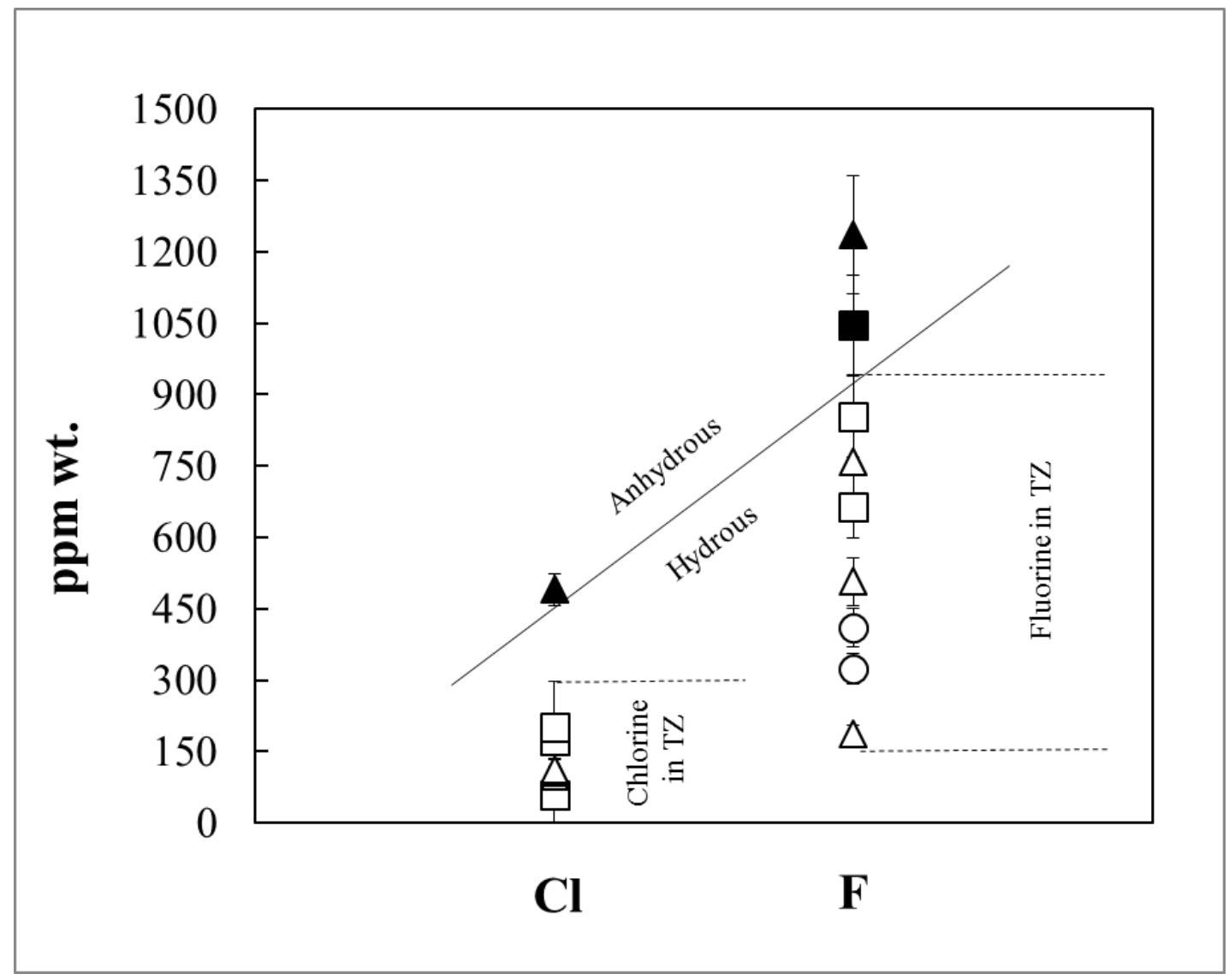


708

Global

Subduction

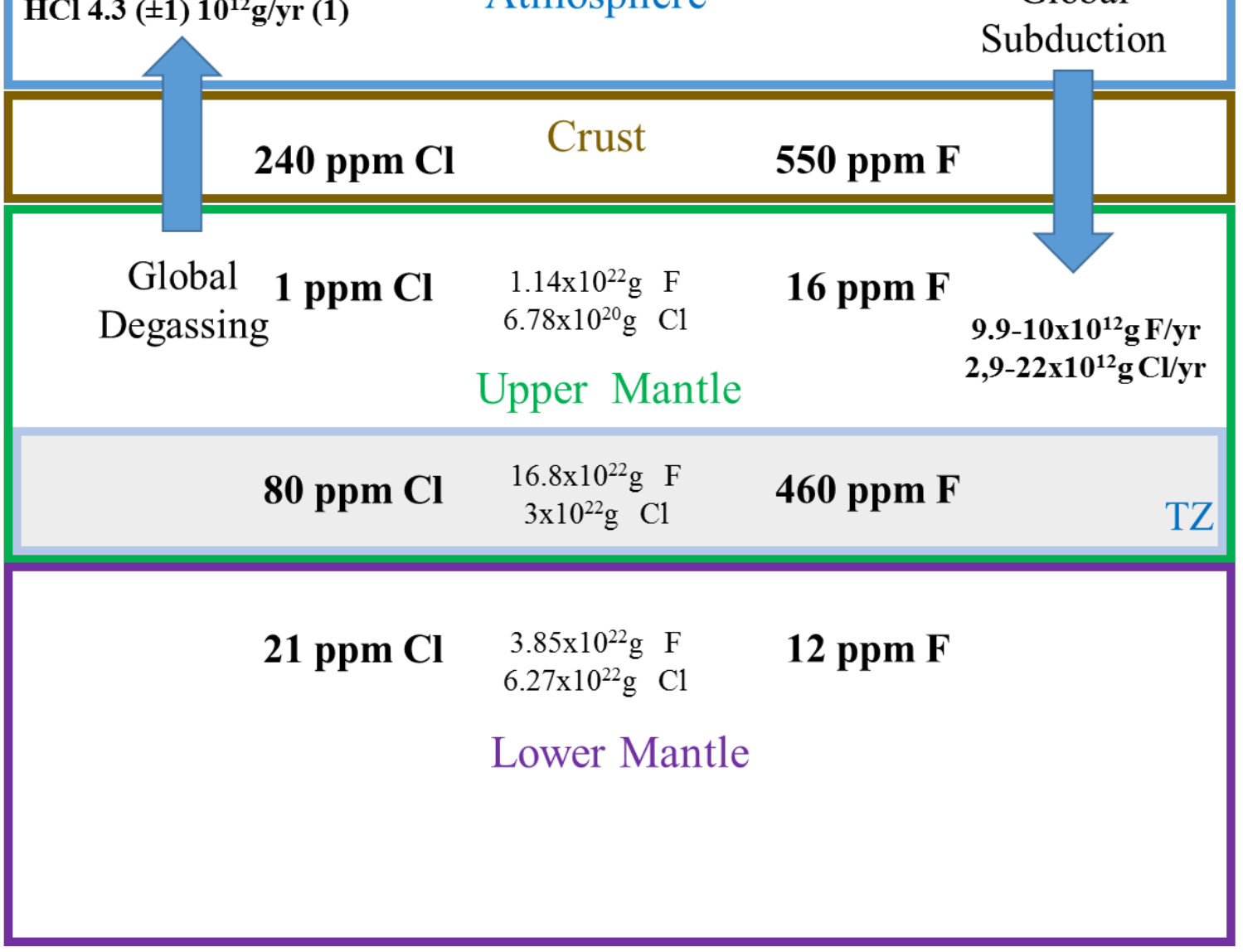


Table 1: Starting materials, experimental conditions and sample descriptions.

\begin{tabular}{|c|c|c|c|c|c|}
\hline Sample & $\begin{array}{c}\mathrm{P} \\
(\mathrm{GPa})\end{array}$ & $\begin{array}{c}\mathrm{T} \\
\left({ }^{\circ} \mathrm{C}\right)\end{array}$ & $\begin{array}{l}\text { Time } \\
(\min )\end{array}$ & Starting material & Phases \\
\hline \multicolumn{6}{|l|}{ References } \\
\hline $83(*)$ & 15 & 1400 & 20 & Pure SC & Wadsleyite (>400 $\mu \mathrm{m})$ \\
\hline H3698(*) & 22 & 1400 & 20 & Pure SC & Ringwoodite $(>400 \mu \mathrm{m})$ \\
\hline \multicolumn{6}{|l|}{ Anhydrous } \\
\hline 87_Cl(*) & 14 & 1350 & 420 & $\begin{array}{c}\mathrm{SCP}+5 \mathrm{wt} . \% \mathrm{NaCl}+2 \mathrm{wt} . \% \\
\mathrm{Mg}(\mathrm{OH})_{2}\end{array}$ & $\begin{array}{c}\text { Wadsleyite }(20 \mu \mathrm{m}) \\
\text { Enstatite } \\
\text { NaCl-glass }\end{array}$ \\
\hline S5551(**) & 20 & 1100 & 240 & $\begin{array}{c}\mathrm{SCP}+5 \mathrm{wt} . \% \mathrm{NaCl}+2 \mathrm{wt} . \% \\
\mathrm{Mg}(\mathrm{OH})_{2}\end{array}$ & $\begin{array}{l}\text { Ringwoodite }(40 \mu \mathrm{m}) \\
\text { Stishovite }(10 \mu \mathrm{m}) \\
\text { NaCl-glass }\end{array}$ \\
\hline \multicolumn{6}{|l|}{ Hydrous } \\
\hline 40_Cl(*) & 14 & 1100 & 240 & $\begin{array}{c}\mathrm{SP}+5 \mathrm{wt} . \% \mathrm{NaCl}+2 \text { wt.\% } \\
\mathrm{Mg}(\mathrm{OH})_{2}\end{array}$ & $\begin{array}{c}\text { Wadsleyite }(40 \mu \mathrm{m}) \\
\text { Enstatite } \\
\text { NaCl-glass }\end{array}$ \\
\hline $86(*)$ & 15 & 1250 & 540 & $\begin{array}{c}\mathrm{SCP}+5 \mathrm{wt} . \% \mathrm{NaCl}+2 \mathrm{wt} . \% \\
\mathrm{Mg}(\mathrm{OH})_{2}\end{array}$ & $\begin{array}{c}\text { Wadsleyite }(30 \mu \mathrm{m}) \\
\text { Enstatite }(10 \mu \mathrm{m}) \\
\text { NaCl-glass }\end{array}$ \\
\hline 88_Cl(*) & 14 & 1400 & 360 & $\begin{array}{c}\mathrm{SCP}+5 \mathrm{wt} . \% \mathrm{NaCl}+2 \mathrm{wt} . \% \\
\mathrm{Mg}(\mathrm{OH})_{2}\end{array}$ & $\begin{array}{l}\text { Wadsleyite }(70 \mu \mathrm{m}) \\
\text { Enstatite }(10 \mu \mathrm{m}) \\
\text { NaCl-glass }\end{array}$ \\
\hline S5553(***) & 20 & 1100 & 240 & $\begin{array}{c}\mathrm{SCP}+5 \mathrm{wt} . \% \mathrm{NaCl}+2 \mathrm{wt} . \% \\
\mathrm{Mg}(\mathrm{OH})_{2}\end{array}$ & $\begin{array}{c}\text { Ringwoodite }(>200 \mu \mathrm{m}) \\
\text { stishovite }(15 \mu \mathrm{m}) \\
\text { NaCl-glass }\end{array}$ \\
\hline H3694(*) & 22 & 1250 & 240 & $\begin{array}{c}\mathrm{SCP}+5 \mathrm{wt} . \% \mathrm{NaCl}+2 \mathrm{wt} . \% \\
\mathrm{Mg}(\mathrm{OH})_{2}\end{array}$ & $\begin{array}{l}\text { Ringwoodite }(100 \mu \mathrm{m}) \\
\text { Stishovite }(20 \mu \mathrm{m}) \\
\text { NaCl-glass }\end{array}$ \\
\hline H3697(*) & 22 & 1400 & 240 & $\begin{array}{c}\mathrm{SCP}+5 \mathrm{wt} . \% \mathrm{NaCl}+2 \mathrm{wt} . \% \\
\mathrm{Mg}(\mathrm{OH})_{2}\end{array}$ & $\begin{array}{c}\text { Ringwoodite }(>300 \mu \mathrm{m}) \\
\text { Stishovite }(20 \mu \mathrm{m}) \\
\text { NaCl-glass }\end{array}$ \\
\hline
\end{tabular}

SC San Carlos olivine, SCP San Carlos olivine powder $+\mathrm{SiO}_{2}$; SP synthetic powder of $\mathrm{SiO}_{2}+\mathrm{MgO}+$ FeO; $\left({ }^{*}\right)$ Au-Pd capsule, $\left({ }^{* *}\right)$ Re capsule, $\left({ }^{* * *}\right)$ Pt capsule, $\mathrm{NaCl}$ pure salt, $\mathrm{Mg}(\mathrm{OH})_{2}$ brucite, Larger grain sizes are given in brackets when measured. 
725 Table 2: Representative analyses of wadsleyites and ringwoodites. Major elements are from EPMA, Cl from PIXE, $\mathrm{H}_{2} \mathrm{O}$ from ERDA.

$726 \mathrm{Wd}=$ wadsleyite, $\mathrm{Rw}$ =ringwoodite, $\mathrm{Nb}=$ number of EPMA analysis, $\mathrm{Mg} \#=\mathrm{Mg} /(\mathrm{Fe}+\mathrm{Mg})$ ratio atomic, $(\mathrm{Fe}+\mathrm{Mg}) / \mathrm{SiO}_{2}$ atomic ratio. Error in brackets is the standard deviation 727 for EPMA analysis and is in (\%) for PIXE and ERDA.

\begin{tabular}{|c|c|c|c|c|c|c|c|c|c|c|c|c|c|c|c|c|c|c|}
\hline \multirow[t]{2}{*}{$\begin{array}{l}\text { Sample } \\
\end{array}$} & \multirow{2}{*}{$\begin{array}{c}\mathrm{P} \\
\pm 1 \mathrm{GPa}\end{array}$} & \multirow{2}{*}{$\begin{array}{c}\mathrm{T} \\
\pm 50^{\circ} \mathrm{C}\end{array}$} & \multirow{2}{*}{$\begin{array}{l}\text { Time } \\
\text { min }\end{array}$} & \multirow[t]{2}{*}{$\begin{array}{l}\text { Phase } \\
\text { Pas }\end{array}$} & \multicolumn{9}{|c|}{ Oxydes (\%wt) } & \multirow[t]{2}{*}{$\mathrm{Nb}$} & \multirow[t]{2}{*}{ Mg\# } & \multirow[t]{2}{*}{$(\mathrm{Mg}+\mathrm{Fe}) / \mathrm{Si}$} & \multicolumn{2}{|c|}{ (ppm) } \\
\hline & & & & & $\overline{\mathrm{SiO}_{2}}$ & $\mathrm{FeO}$ & $\mathrm{MnO}$ & $\mathrm{Al}_{2} \mathrm{O}_{3}$ & $\mathrm{Na}_{2} \mathrm{O}$ & $\mathrm{MgO}$ & $\mathrm{CaO}$ & $\mathrm{TiO}_{2}$ & Total & & & & $\mathrm{H}_{2} \mathrm{O}$ & $\mathrm{Cl}$ \\
\hline \multicolumn{19}{|c|}{ Reference } \\
\hline 83 & 15 & 1400 & 20 & Wd & $\begin{array}{l}41.55 \\
(0.09)\end{array}$ & $\begin{array}{c}9.21 \\
(0.10)\end{array}$ & $\begin{array}{c}0.12 \\
(0.04)\end{array}$ & $\begin{array}{c}0.11 \\
(0.02)\end{array}$ & $\begin{array}{c}0.02 \\
(0.02)\end{array}$ & $\begin{array}{l}48.48 \\
(0.29)\end{array}$ & $\begin{array}{c}0.02 \\
(0.03)\end{array}$ & $\begin{array}{c}0.01 \\
(0.01)\end{array}$ & $\begin{array}{c}99.63 \\
(0.38)\end{array}$ & 9 & 0.90 & 1.92 & & \\
\hline H3698 & 22 & 1400 & 20 & $\mathrm{Rw}$ & $\begin{array}{l}41.50 \\
(0.31) \\
\end{array}$ & $\begin{array}{c}9.70 \\
(0.14) \\
\end{array}$ & $\begin{array}{c}0.12 \\
(0.05) \\
\end{array}$ & $\begin{array}{c}0.04 \\
(0.04) \\
\end{array}$ & $\begin{array}{c}0.01 \\
(0.01) \\
\end{array}$ & $\begin{array}{l}48.79 \\
(0.27) \\
\end{array}$ & $\begin{array}{c}0.07 \\
(0.02) \\
\end{array}$ & $\begin{array}{c}0.01 \\
(0.02) \\
\end{array}$ & $\begin{array}{l}100.39 \\
(0.38)\end{array}$ & 14 & 0.90 & 1.95 & & \\
\hline \multicolumn{19}{|c|}{ Anhydrous } \\
\hline 87_Cl & 14 & 1350 & 420 & Wd & $\begin{array}{l}41.38 \\
(0.39)\end{array}$ & $\begin{array}{c}8.56 \\
(0.16)\end{array}$ & $\begin{array}{c}0.08 \\
(0.03)\end{array}$ & $\begin{array}{c}0.07 \\
(0.02)\end{array}$ & $\begin{array}{c}0.16 \\
(0.03)\end{array}$ & $\begin{array}{l}48.87 \\
(0.42)\end{array}$ & $\begin{array}{c}0.03 \\
(0.03)\end{array}$ & $\begin{array}{c}0.03 \\
(0.02)\end{array}$ & $\begin{array}{l}99.18 \\
(0.21)\end{array}$ & 7 & 0.91 & 1.93 & & ND \\
\hline S5551 & 20 & 1100 & 240 & $\mathrm{Rw}$ & $\begin{array}{l}41.40 \\
(0.86)\end{array}$ & $\begin{array}{c}9.00 \\
(0.33)\end{array}$ & $\begin{array}{c}0.14 \\
(0.04)\end{array}$ & $\begin{array}{c}0.05 \\
(0.03)\end{array}$ & $\begin{array}{c}0.06 \\
(0.04)\end{array}$ & $\begin{array}{l}47.84 \\
(0.93)\end{array}$ & $\begin{array}{c}0.04 \\
(0.01)\end{array}$ & $\begin{array}{c}0.01 \\
(0.01)\end{array}$ & $\begin{array}{l}98.54 \\
(0.29)\end{array}$ & 4 & 0.90 & 1.91 & & $\begin{array}{l}490 \\
\text { (33) }\end{array}$ \\
\hline
\end{tabular}

\begin{tabular}{|c|c|c|c|c|c|c|c|c|c|c|c|c|c|c|c|c|c|c|}
\hline Hydrou & & & & & & & & & & & & & & & & & & \\
\hline 40_Cl & 14 & 1100 & 240 & Wd & $\begin{array}{l}41.13 \\
(0.34)\end{array}$ & $\begin{array}{c}8.84 \\
(0.20)\end{array}$ & $\begin{array}{c}0.02 \\
(0.02)\end{array}$ & $\begin{array}{c}0.24 \\
(0.04)\end{array}$ & $\begin{array}{c}0.22 \\
(0.05)\end{array}$ & $\begin{array}{l}49.09 \\
(0.52)\end{array}$ & $\begin{array}{c}0.02 \\
(0.01)\end{array}$ & $\begin{array}{c}0.02 \\
(0.03)\end{array}$ & $\begin{array}{l}99.58 \\
(0.75)\end{array}$ & 6 & 0.91 & 1.96 & $\begin{array}{l}917 \\
(15)\end{array}$ & $\begin{array}{l}174 \\
(22)\end{array}$ \\
\hline 86 & 15 & 1250 & 540 & Wd & $\begin{array}{l}41.49 \\
(0.46)\end{array}$ & $\begin{array}{c}8.57 \\
(0.13)\end{array}$ & $\begin{array}{c}0.09 \\
(0.03)\end{array}$ & $\begin{array}{c}0.08 \\
(0.01)\end{array}$ & $\begin{array}{c}0.19 \\
(0.03)\end{array}$ & $\begin{array}{l}48.88 \\
(0.34)\end{array}$ & $\begin{array}{c}0.00 \\
(0.00)\end{array}$ & $\begin{array}{c}0.02 \\
(0.02)\end{array}$ & $\begin{array}{l}99.32 \\
(0.47)\end{array}$ & 6 & 0.91 & 1.93 & $\begin{array}{l}1659 \\
(14)\end{array}$ & $\begin{array}{c}60 \\
(60)\end{array}$ \\
\hline 88_Cl & 14 & 1400 & 360 & Wd & $\begin{array}{l}41.55 \\
(0.20)\end{array}$ & $\begin{array}{c}8.04 \\
(0.20)\end{array}$ & $\begin{array}{c}0.05 \\
(0.03)\end{array}$ & $\begin{array}{c}0.09 \\
(0.02)\end{array}$ & $\begin{array}{c}0.19 \\
(0.02)\end{array}$ & $\begin{array}{l}49.65 \\
(0.24)\end{array}$ & $\begin{array}{c}0.01 \\
(0.01)\end{array}$ & $\begin{array}{c}0.02 \\
(0.02)\end{array}$ & $\begin{array}{c}99.6 \\
(0.35)\end{array}$ & 6 & 0.92 & 1.94 & $\begin{array}{l}1115 \\
(14)\end{array}$ & $\begin{array}{l}200 \\
(48)\end{array}$ \\
\hline S5553 & 20 & 1100 & 240 & Rw & $\begin{array}{l}41.63 \\
(0.22)\end{array}$ & $\begin{array}{c}7.63 \\
(0.13)\end{array}$ & $\begin{array}{c}0.07 \\
(0.03)\end{array}$ & $\begin{array}{c}0.03 \\
(0.02)\end{array}$ & $\begin{array}{c}0.04 \\
(0.01)\end{array}$ & $\begin{array}{l}49.42 \\
(0.04)\end{array}$ & $\begin{array}{c}0.00 \\
(0.00)\end{array}$ & $\begin{array}{c}0.02 \\
(0.02)\end{array}$ & $\begin{array}{l}98.84 \\
(0.42)\end{array}$ & 3 & 0.92 & 1.92 & $\begin{array}{l}4766 \\
(13)\end{array}$ & $\begin{array}{c}99 \\
(12)\end{array}$ \\
\hline H3694 & 22 & 1250 & 240 & $\mathrm{Rw}$ & $\begin{array}{l}40.49 \\
(0.55)\end{array}$ & $\begin{array}{c}7.67 \\
(0.07)\end{array}$ & $\begin{array}{c}0.04 \\
(0.04)\end{array}$ & $\begin{array}{c}0.07 \\
(0.00)\end{array}$ & $\begin{array}{c}0.09 \\
(0.04)\end{array}$ & $\begin{array}{l}49.97 \\
(0.42)\end{array}$ & $\begin{array}{c}0.00 \\
(0.01)\end{array}$ & $\begin{array}{c}0.03 \\
(0.02)\end{array}$ & $\begin{array}{l}98.36 \\
(0.30)\end{array}$ & 3 & 0.92 & 2.00 & $\begin{array}{l}932 \\
(14)\end{array}$ & $\begin{array}{l}106 \\
\text { (26) }\end{array}$ \\
\hline H3697 & 22 & 1400 & 240 & Rw & $\begin{array}{l}41.37 \\
(0.37)\end{array}$ & $\begin{array}{c}8.18 \\
(0.34)\end{array}$ & $\begin{array}{c}0.07 \\
(0.02)\end{array}$ & $\begin{array}{c}0.06 \\
(0.02)\end{array}$ & $\begin{array}{c}0.10 \\
(0.05)\end{array}$ & $\begin{array}{l}49.57 \\
(0.35)\end{array}$ & $\begin{array}{c}0.01 \\
(0.01)\end{array}$ & $\begin{array}{c}0.02 \\
(0.02)\end{array}$ & $\begin{array}{l}99.38 \\
(0.29)\end{array}$ & 7 & 0.92 & 1.95 & $\begin{array}{l}1554 \\
(13)\end{array}$ & $\begin{array}{l}113 \\
(20)\end{array}$ \\
\hline
\end{tabular}

729 
731 